\title{
C-H-Functionalization logic guides the synthesis of a carbacyclopamine analog
}

\author{
Sebastian Rabe ${ }^{1}$, Johann Moschner ${ }^{1}$, Marina Bantzi ${ }^{1}$, Philipp Heretsch ${ }^{*}$ \\ and Athanassios Giannis*1
}

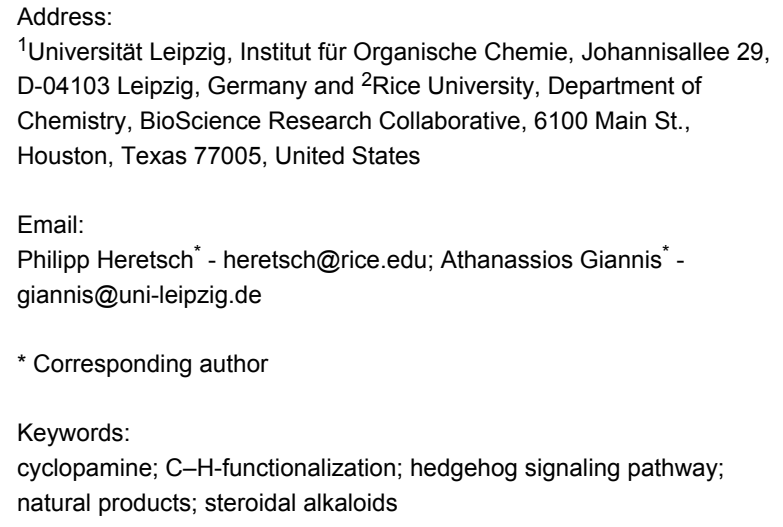

Beilstein J. Org. Chem. 2014, 10, 1564-1569.

doi:10.3762/bjoc. 10.161

Received: 16 April 2014

Accepted: 23 June 2014

Published: 09 July 2014

This article is part of the Thematic Series "Natural products in synthesis and biosynthesis".

Guest Editor: J. S. Dickschat

(C) 2014 Rabe et al; licensee Beilstein-Institut. License and terms: see end of document.

\begin{abstract}
The chemical synthesis of carbacyclopamine analog 2, a cyclopamine analog with an all-carbon E-ring, is reported. The use of $\mathrm{C}-\mathrm{H}$-functionalization logic and further metal-catalyzed transformations allows for a concise entry to this new class of acid-stable cyclopamine analogs.
\end{abstract}

\section{Introduction}

The isolation of cyclopamine (1, Figure 1) nearly 50 years ago followed by the determination of its biological target and pharmacological profile has drawn considerable interest from research groups in biology, chemistry and medicine [1-4]. As the first identified hedgehog signaling inhibitor, cyclopamine exerts its anticancer activity through a novel mechanism of action, which manifests itself in its remarkable activity against several types of human cancer, including medulloblastoma, basal cell carcinoma, and rhabdomyosarcoma [5-10]. The impressive biological activity combined with a unique molecular architecture and the synthetic challenge it poses already let to the first synthesis of cyclopamine by this laboratory employing $\mathrm{C}-\mathrm{H}$-functionalization logic [11]. In addition, the rational design and chemical synthesis of several analogs and derivatives by this [12,13] and other groups [14-17] have been disclosed. Here, we report the synthesis of a carbacyclopamine analog (2, Figure 1), an analog of the natural product with an all-carbon E-ring and a pyridine F-ring.

Cyclopamine inhibits the 7-transmembrane protein smoothened from converting into its active form $[18,19]$. Without active smoothened, protein kinases like PKA, GSK $3 \beta$, and CK1 $1 \varepsilon$ phosphorylate the transcription factors Gli2 and Gli3, thereby creating binding sites for the adapter protein $\beta$-TrCP [20]. The 


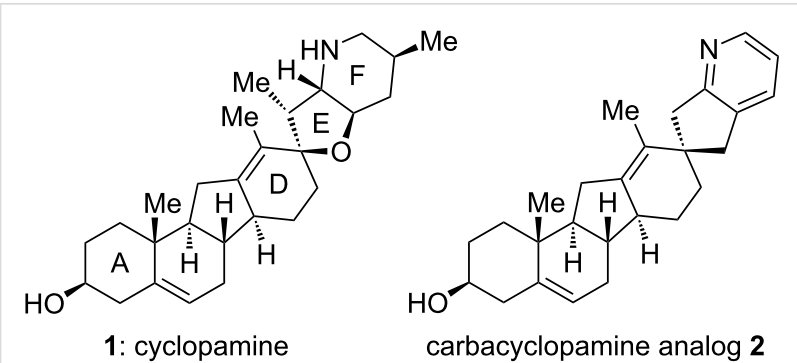

Figure 1: Structures of cyclopamine (1) and carbacyclopamine analog

Gli family of transcription factors acts as an effector of the hedgehog signaling pathway and thus, is associated with a wide array of physiological effects, including cell fate determination, proliferation and patterning. The so-formed Gli/ $\beta$-TrCP complex becomes subject to ubiquitinylation, mediated by the Cul1based E3 ligase. Eventually, this results in partial proteosomal degradation to form Gli3-R [21], or in the case of Gli2 [22,23], in complete degradation. In addition, the Gli3-R factor acts as a transcription inhibitor of hedgehog-response genes [10].

As part of our continuing work on acid-stable cyclopamine analogs $[12,13]$ we have now focused on the role of the allylic ether oxygen in the acid-mediated E-ring cleavage and decomposition of cyclopamine [24]. We envisioned that its replacement by a methylene group would create an acid-stable cyclopamine analog that still exhibits similar inhibitory activity on hedgehog-signaling. For the sake of brevity of the overall synthetic sequence we defined carbacyclopamine analog $\mathbf{2}$ (see Figure 1) as our primary target.

\section{Results and Discussion}

A retrosynthetic analysis identified diazo compound $\mathbf{3}$ as a key intermediate in the synthesis of $\mathbf{2}$ (see Scheme 1). We envisioned a rhodium-catalyzed $\mathrm{C}-\mathrm{H}$-insertion into the $\mathrm{C} 17-\mathrm{H}$ bond to occur with a high degree of selectivity (both regio- and stereoselectivity) to form the all-carbon E-ring (for its structure see 11, Scheme 2). Furthermore, a Wagner-Meerwein rearrangement was thought to establish the C-nor-D-homo steroid system, and a gold-catalyzed amination/annulation/ aromatization sequence was planned to install the pyridine F-ring. Diazo compound 3 originates from diene $\mathbf{4}$ through standard transformations, the latter being accessible from commercially available and inexpensive dehydroepiandrosterone (5) by the means of a copper-mediated $\mathrm{C}-\mathrm{H}$ hydroxylation in the 12-position and a palladium-catalyzed coupling of methyl acrylate to an activated enol ether in the 17-position.

In synthetic direction (Scheme 2), dehydroepiandrosterone (5) was protected as its tetrahydropyranyl ether (3,4-dihydro- $2 \mathrm{H}$ pyran, cat. pyridinium para-toluenesulfonate, $\mathrm{CH}_{2} \mathrm{Cl}_{2}, 25{ }^{\circ} \mathrm{C}$, quantiative, inconsequential mixture of diastereoisomers), and the $\mathrm{C} 17$ carbonyl group was transformed into its 2-picolylimine

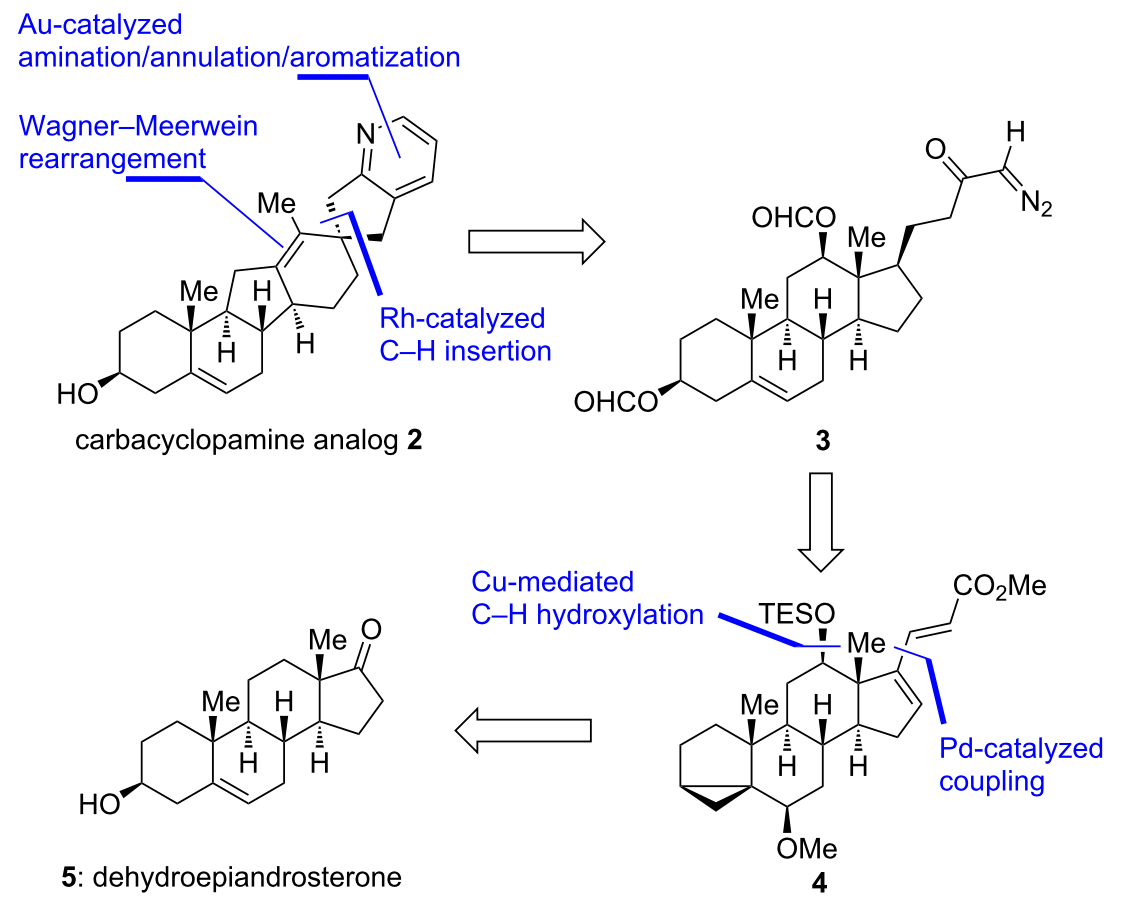

Scheme 1: Retrosynthetic analysis of carbacyclopamine analog 2. 


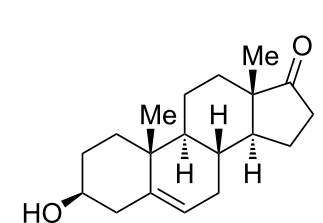

5: dehydroepiandrosterone

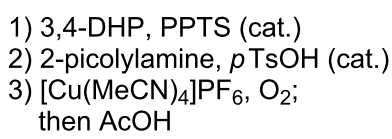

1) 3,4-DHP, PPTS (cat.)

2) 2-picolylamine, $p \mathrm{TsOH}$ (cat.)

3) $\left[\mathrm{Cu}(\mathrm{MeCN})_{4}\right] \mathrm{PF}_{6}, \mathrm{O}_{2}$;

then $\mathrm{AcOH}$

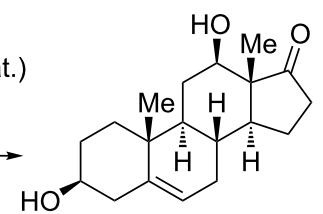

1) TESOTf, 2,6-lutidine 2) HF.py

$67 \%$ for 2 steps

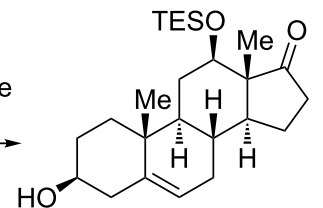

7

1) $\mathrm{TsCl}, \mathrm{DMAP}$ (cat.)

2) $\mathrm{KOAc}, \mathrm{MeOH}$

$85 \%$ for 2 steps

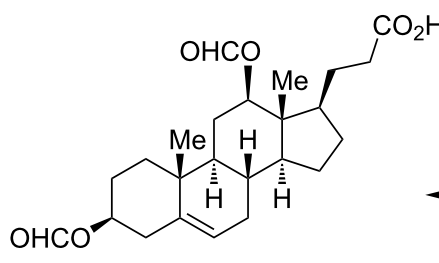

10

1) $(\mathrm{COCl})_{2}$

2) $\mathrm{CH}_{2} \mathrm{~N}_{2}$

3) $\mathrm{Rh}_{2}(\mathrm{OAc})_{4}$ (cat.)

$44 \%$ for 3 steps
1) $p \mathrm{TsOH}$ (cat.), $\mathrm{H}_{2} \mathrm{O}$

2) $\mathrm{LiOH}, \mathrm{H}_{2} \mathrm{O}$

3) $\mathrm{HCOOH}$

$57 \%$ for 3 steps

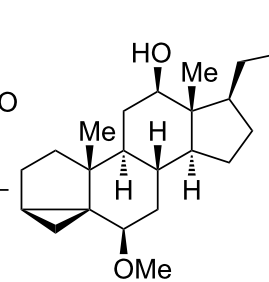

$\mathrm{CO}_{2} \mathrm{Me}$ 1) KHMDS, $\mathrm{PhNTf}_{2}$ 2) methyl acrylate, $\mathrm{Pd}(\mathrm{OAc})_{2}$ (cat.), $\mathrm{PPh}_{3}$ (cat.) 3) $\mathrm{Pd} / \mathrm{C}$ (cat.), $\mathrm{H}_{2}$ $45 \%$ for 3 steps

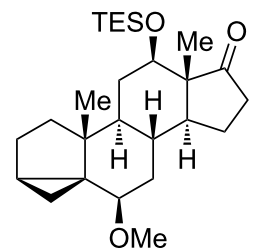
8

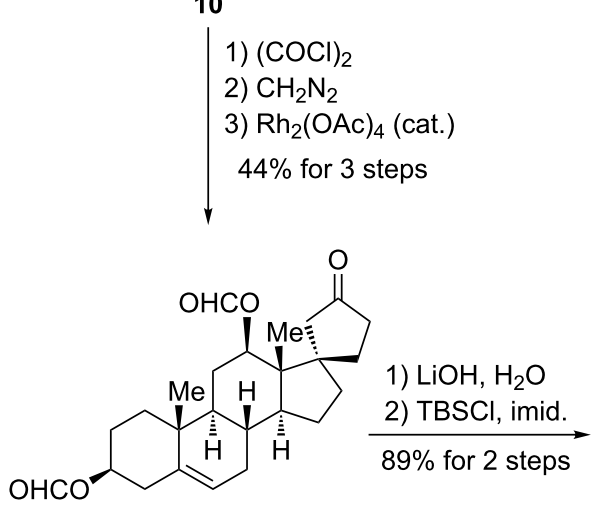

11<smiles>Nc1ccc(Cl)cn1</smiles>

Comins' reagent

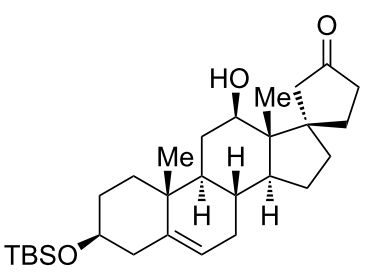

12

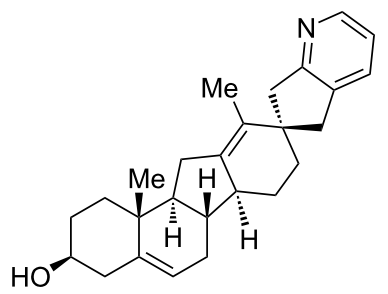

carbacyclopamine analog 2

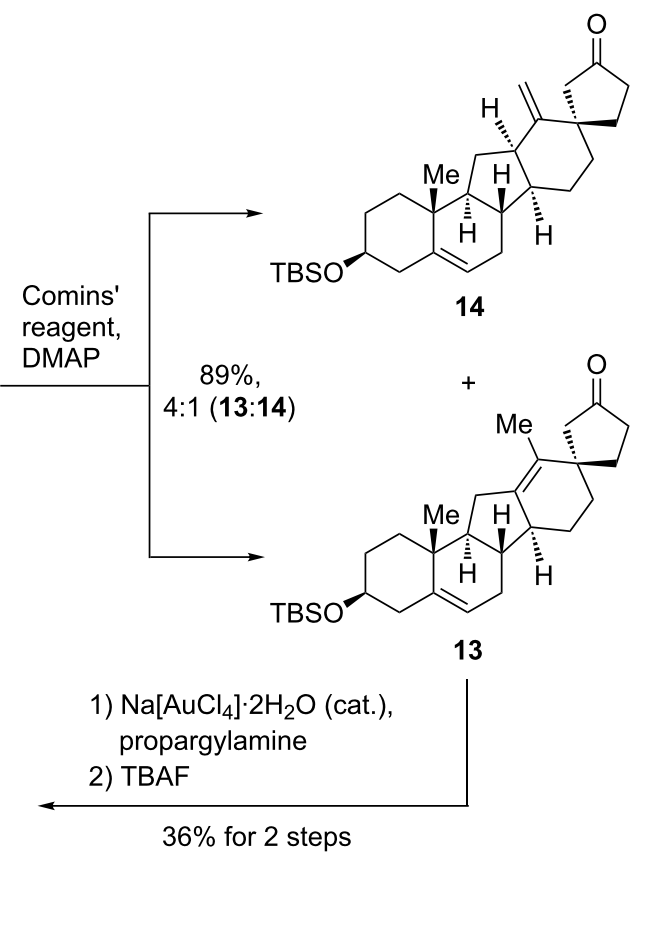

Scheme 2: Synthesis of carbacyclopamine analog 2.

(2-picolylamine, cat. para-toluenesulfonic acid, toluene, $111{ }^{\circ} \mathrm{C}, 92 \%$ yield). Subjecting the latter to modified Schönecker conditions $\left(\left[\mathrm{Cu}(\mathrm{MeCN})_{4}\right] \mathrm{PF}_{6}, \mathrm{O}_{2}\right.$, acetone, $\left.25^{\circ} \mathrm{C}\right)$ [25-27], gave, after acidic work-up ( $\left.\mathrm{AcOH} / \mathrm{MeOH}, 1: 1,90^{\circ} \mathrm{C}\right)$, diol 6 in $46 \%$ yield as the only isolable product. Protection of the newly installed $12 \beta$-hydroxy group as a triethylsilyl ether via the bis-protected intermediate (not shown, triethylsilyl trifluoromethanesulfonate, 2,6-lutidine, $\mathrm{CH}_{2} \mathrm{Cl}_{2}, 0{ }^{\circ} \mathrm{C}$; then HF-pyridine, THF, $0{ }^{\circ} \mathrm{C}, 67 \%$ yield for the two steps) [28] gave hydroxy ketone 7 .
The remaining homoallylic alcohol was then masked as an $i$-steroid [29,30] (para-toluenesulfonyl chloride, cat. 4-dimethylaminopyridine, pyridine, $25^{\circ} \mathrm{C}$; then $\mathrm{KOAc}, \mathrm{MeOH}$, $64{ }^{\circ} \mathrm{C}, 85 \%$ yield for the two steps) to give 8 . Generation of an enol triflate from the carbonyl group in $\mathbf{8}$ (potassium hexamethyldisilazide, phenyl bis-triflimide, THF, $-20 \rightarrow-10{ }^{\circ} \mathrm{C}, 85 \%$ yield) set stage for a Heck-reaction with methyl acrylate (cat. $\mathrm{Pd}(\mathrm{OAc})_{2}$, cat. $\mathrm{PPh}_{3}, \mathrm{Et}_{3} \mathrm{~N}, \mathrm{DMF}, 70{ }^{\circ} \mathrm{C}, 64 \%$ yield $)$. The hydrogenation of the so-obtained diene 4 (for its structure see Scheme 1) proceeded smoothly $\left(\mathrm{H}_{2}\right.$, cat. $\mathrm{Pd} / \mathrm{C}, \mathrm{MeOH}, 25^{\circ} \mathrm{C}$, 
$82 \%$ yield) under concomitant removal of the triethylsilyl ether [31] in 12-position to give methyl ester 9 as a single diastereoisomer. At this point, extensive experimentation suggested a change of protecting groups to enable the pending $\mathrm{C}-\mathrm{H}$ insertion reaction at $\mathrm{C} 17$.

Therefore, the $i$-steroid was reverted to the homoallylic alcohol (cat. para-toluenesulfonic acid, 1,4-dioxane $/ \mathrm{H}_{2} \mathrm{O}, 10: 1,65^{\circ} \mathrm{C}$ ), the methyl ester was hydrolyzed under basic conditions $(\mathrm{LiOH}$, $\mathrm{THF} / \mathrm{H}_{2} \mathrm{O}, 1: 1,68 \%$ yield for the two steps), and the alcohol moieties were protected as formyl esters (formic acid, $50{ }^{\circ} \mathrm{C}$, $85 \%$ yield) to give key intermediate $\mathbf{1 0}$.

Employing the formyl protecting groups [32], diazoketone 3 (for its structure see Scheme 1) was readily obtained from acid 10 via the corresponding acid chloride (oxalyl chloride, $\mathrm{CH}_{2} \mathrm{Cl}_{2}, 25^{\circ} \mathrm{C}$; then diazomethane, THF, $25{ }^{\circ} \mathrm{C}, 85 \%$ yield for the two steps) [33]. The anticipated $\mathrm{C}-\mathrm{H}$ insertion then proceeded uneventfully under oxygen-free conditions (cat. $\left.\mathrm{Rh}_{2}(\mathrm{OAc})_{4}, \mathrm{CH}_{2} \mathrm{Cl}_{2}, 41^{\circ} \mathrm{C}\right)[34,35]$ to give cyclopentanone $\mathbf{1 1}$ in $52 \%$ yield as a single isomer. Removal of the formyl ester protecting groups $\left(\mathrm{LiOH}, \mathrm{THF} / \mathrm{H}_{2} \mathrm{O}, 1: 1,30{ }^{\circ} \mathrm{C}, 94 \%\right.$ yield) and selective protection of the 3-hydroxy group as a tert-butyldimethylsilyl ether (tert-butyldimethylsilyl chloride, imidazole, DMF, $25{ }^{\circ} \mathrm{C}, 95 \%$ yield) furnished alcohol 12 .

Treatment of the latter under our previously reported conditions [36] (Comins' reagent, 4-dimethylaminopyridine, toluene, $111^{\circ} \mathrm{C}$ ) gave an inseparable mixture of the rearranged olefin products, with the desired endo-product $\mathbf{1 3}$ as the major constituent (89\% combined yield, endo-product 13:exo-product $\mathbf{1 4}, 4: 1)$. Isolation of desired product 13 by chromatography was then achieved after selective hydrogenation of only the exocyclic olefin in $\mathbf{1 4}\left(\mathrm{H}_{2}\right.$, cat. $\mathrm{Rh} / \mathrm{C}$, EtOAc, $25^{\circ} \mathrm{C}$, structure of hydrogenation product not shown) employing the mixture of the isomers $\mathbf{1 3}$ and $\mathbf{1 4}$ from the previous step.

Finally, a gold-catalyzed amination/annulation/aromatization sequence (propargylamine, cat. $\mathrm{Na}\left[\mathrm{AuCl}_{4}\right] \cdot 2 \mathrm{H}_{2} \mathrm{O}, \mathrm{EtOH}$, $100{ }^{\circ} \mathrm{C}$ ) [37,38] furnished, after removal of the tert-butyldimethylsilyl ether (tetrabutylammonium fluoride, THF, $25^{\circ} \mathrm{C}$ ), carbacyclopamine analog 2 in $36 \%$ overall yield for the two steps [39].

Carbacyclopamine analog $\mathbf{2}$ was then tested for its stability towards acid. Therefore, 2 was treated with a mixture of aqueous $\mathrm{HCl} / \mathrm{THF}$ ( $\mathrm{pH}$ of approx. 0.3) for $1 \mathrm{~h}$ and ${ }^{1} \mathrm{H}$ NMR spectra were recorded before and afterwards. While at this $\mathrm{pH}$ natural cyclopamine (1) was shown to decompose rapidly [12], carbacyclopamine analog 2 showed no signs of decomposition. This result was in full agreement with our initial considerations.
To determine the ability of carbacyclopamine analog 2 to inhibit Gli1-dependent luciferase expression, we employed ShhLIGHTII cells, a clonal mouse fibroblast cell line which stably incorporates a Gli-dependent firefly luciferase reporter and a constitutive Renilla luciferase reporter [18]. The analog was tested in a concentration range from $0.01 \mu \mathrm{M}$ to $100 \mu \mathrm{M}$ but showed no activity (data not shown).

\section{Conclusion}

We have reported the synthesis of a new, acid stable cyclopamine analog. The implementation of $\mathrm{C}-\mathrm{H}$-functionalization logic in the synthetic planning and further metal-catalyzed transformations allows for a fast access to carbocyclopamine analog 2. At the same time, these investigations strongly suggest the role the ether oxygen plays in the acid-catalyzed decomposition of cyclopamine. This study may find further application in the rational design of new hedgehog inhibitors based on lead structure 2. Future work will focus on the synthesis of carbacyclopamine analogs with a piperidine F-ring and their biological investigation.

\section{Supporting Information}

\section{Supporting Information File 1}

Experimental procedures, characterization data, and copies of ${ }^{1} \mathrm{H}$ and ${ }^{13} \mathrm{C}$ NMR spectra for new compounds. [http://www.beilstein-journals.org/bjoc/content/ supplementary/1860-5397-10-161-S1.pdf]

\section{Acknowledgements}

We thank Dr. Lothar Hennig, Universität Leipzig, for his help with recording and interpreting the 2D NMR spectra.

\section{References}

1. Keeler, R. F. Phytochemistry 1968, 7, 303-306. doi:10.1016/S0031-9422(00)86328-1

2. Keeler, R. F. Teratology 1970, 3, 169-174. doi:10.1002/tera.1420030209

3. Beachy, P. A.; Karhadkar, S. S.; Berman, D. M. Nature 2004, 432, 324-331. doi:10.1038/nature03100

4. Taipale, J.; Beachy, P. A. Nature 2001, 411, 349-354. doi: $10.1038 / 35077219$

5. Hidalgo, M.; Maitra, A. N. Engl. J. Med. 2009, 361, 2094-2096. doi:10.1056/NEJMcibr0905857

6. Dierks, C.; Grbic, J.; Zirlik, K.; Beigi, R.; Englund, N. P.; Guo, G.-R.; Veelken, H.; Engelhardt, M.; Mertelsmann, R.; Kelleher, J. F.; Schultz, P.; Warmuth, M. Nat. Med. 2007, 13, 944-951. doi:10.1038/nm1614

7. Hedge, G. V.; Munger, C. M.; Emanuel, K.; Joshi, A. D.; Greiner, T. C.; Weisenburger, D. D.; Vose, J. M.; Joshi, S. S. Mol. Cancer Ther. 2008, 7, 1450-1460. doi:10.1158/1535-7163.MCT-07-2118 
8. Kawahara, T.; Kawaguchi-Ihara, N.; Okuhashi, Y.; Itoh, M.; Nara, N.; Tohda, S. Anticancer Res. 2009, 29, 4629-4632.

9. Heretsch, P.; Tzagkaroulaki, L.; Giannis, A. Angew. Chem., Int. Ed. 2010, 49, 3418-3427. doi:10.1002/anie.200906967

10. Heretsch, P.; Tzagkaroulaki, L.; Giannis, A. Bioorg. Med. Chem. 2010, 18, 6613-6624. doi:10.1016/j.bmc.2010.07.038 And references cited therein.

11. Giannis, A.; Heretsch, P.; Sarli, V.; Stößel, A. Angew. Chem., Int. Ed. 2009, 48, 7911-7914. doi:10.1002/anie.200902520

12. Heretsch, P.; Büttner, A.; Tzagkaroulaki, L.; Zahn, S.; Kirchner, B.; Giannis, A. Chem. Commun. 2011, 47, 7362-7364. doi:10.1039/C1CC11782C

13. Moschner, J.; Chentsova, A.; Eilert, N.; Rovardi, I.; Heretsch, P.; Giannis, A. Beilstein J. Org. Chem. 2013, 9, 2328-2335. doi:10.3762/bjoc.9.267

14. Tremblay, M. R.; Nevalainen, M.; Nair, S. J.; Porter, J. R.; Castro, A. C.; Behnke, M. L.; Yu, L.-C.; Hagel, M.; White, K.; Faia, K.; Grenier, L.; Campbell, M. J.; Cushing, J.; Woodward, C. N.; Hoyt, J.; Foley, M. A.; Read, M. A.; Sydor, J. R.; Tong, J. K.; Palombella, V. J.; McGovern, K.; Adams, J. J. Med. Chem. 2008, 51, 6646-6649. doi:10.1021/jm8008508

15. Tremblay, M. R.; Lescarbeau, A.; Grogan, M. J.; Tan, E.; Lin, G.; Austad, B. C.; Yu, L.-C.; Behnke, M. L.; Nair, S. J.; Hagel, M.; White, K.; Conley, J.; Manna, J. D.; Alvarez-Diez, T. M.; Hoyt, J.; Woodward, C. N.; Sydor, J. R.; Pink, M.; MacDougall, J.; Campbell, M. J.; Cushing, J.; Ferguson, J.; Curtis, M. S.; McGovern, K.; Read, M. A.; Palombella, V. J.; Adams, J.; Castro, A. C. J. Med. Chem. 2009, 52, 4400-4418. doi:10.1021/jm900305z

16. Zhang, Z.; Baubet, V.; Ventocilla, C.; Xiang, C.; Dahmane, N.; Winkler, J. D. Org. Lett. 2011, 13, 4786-4789. doi:10.1021/ol2017966

17. Winkler, J. D.; Isaacs, A.; Holderbaum, L.; Tatard, V.; Dahmane, N. Org. Lett. 2009, 11, 2824-2827. doi:10.1021/ol900974u

18. Taipale, J.; Chen, J. K.; Cooper, M. K.; Wang, B.; Mann, R. K.; Milenkovic, L.; Scott, M. P.; Beachy, P. A. Nature 2000, 406, 1005-1009. doi:10.1038/35023008

19. Wang, Y.; Zhou, Z.; Walsh, C. T.; McMahon, A. P. Proc. Natl. Acad. Sci. U. S. A. 2009, 106, 2623-2628. doi:10.1073/pnas.0812110106

20. Pearse, R. V., II; Collier, L.S.; Scott, M. P.; Tabin, C. J. Dev. Biol. 1999, 212, 323-336. doi:10.1006/dbio.1999.9335

21. Wen, X.; Lai, C. K.; Evangelista, M.; Hongo, J.-A.; de Sauvage, F. J.; Scales, S. J. Mol. Cell. Biol. 2010, 30, 1910-1922. doi:10.1128/MCB.01089-09

22. Pan, Y.; Bai, C. B.; Joyner, A. L.; Wang, B. Mol. Cell. Biol. 2006, 26, 3365-3377. doi:10.1128/MCB.26.9.3365-3377.2006

23. Wang, B.; Fallon, J. F.; Beachy, P. A. Cell 2000, 100, 423-434. doi:10.1016/S0092-8674(00)80678-9

24. Wilson, S. R.; Strand, M. F.; Krapp, A.; Rise, F.; Petersen, D.; Krauss, S. J. Pharm. Biomed. Anal. 2010, 52, 707-713. doi:10.1016/j.jpba.2010.02.017

See for a proposed mechanism of the decomposition of cyclopamine. For a discussion of the molecular orbitals involved in the process, see ref. [12.]

25. Schönecker, B.; Zheldakova, T.; Lange, C.; Günther, W.; Görls, H.; Bohl, M. Chem.-Eur. J. 2004, 10, 6029-6042. doi:10.1002/chem.200306054

26. Schönecker, B.; Zheldakova, T.; Liu, Y.; Kötteritzsch, M.; Günther, W.; Görls, H. Angew. Chem., Int. Ed. 2003, 42, 3240-3244.

doi:10.1002/anie.200250815
27. Schönecker, B.; Lange, C.; Zheldakova, T.; Günther, W.; Görls, H.; Vaughan, G. Tetrahedron 2005, 61, 103-114. doi:10.1016/j.tet.2004.10.055

28. Ojima, I.; Chen, J.; Sun, L.; Borella, C. P.; Wang, T.; Miller, M. L.; Lin, S.; Geng, X.; Kuznetsova, L.; Qu, C.; Gallager, D.; Zhao, X.; Zanardi, I.; Xia, S.; Horwitz, S. B.; Mallen-St. Clair, J.; Guerriero, J. L.; Bar-Sagi, D.; Veith, J. M.; Pera, P.; Bernacki, R. J. J. Med. Chem. 2008, 51, 3203-3221. doi:10.1021/jm800086e

29. Fernholz, E.; Ruigh, W. L. J. Am. Chem. Soc. 1940, 62, 3346-3348. doi:10.1021/ja01869a022

30. Wallis, E. S.; Fernholz, E.; Gephart, F. T. J. Am. Chem. Soc. 1937, 59, 137-140. doi:10.1021/ja01280a034

31. Rotulo-Sims, D.; Prunet, J. Org. Lett. 2002, 4, 4701-4704. doi: $10.1021 / 010271382$

32. The formyl groups were chosen both for the ease of their installation, and a considerably lower sterical demand in the pending cyclization event when compared to other protective groups. Using triethylsilyl ethers or allyl ethers instead did not allow for the generation of the desired diazo-compound. The use of acetyl protecting groups led to the formation of seven-membered lactone $\mathbf{2 5}$ (for experimental details see Supporting Information File 1).

33. A similar reaction employing diazoethane instead of diazomethane gave the methyl homolog of compound 10. All attempts to effect the $\mathrm{C}-\mathrm{H}$ insertion were met with failure, though (see Supporting Information File 1 for experimental details).

34. Nakamura, E.; Yoshikai, N.; Yamanaka, M. J. Am. Chem. Soc. 2002, 124, 7181-7192. doi:10.1021/ja017823o

35. Doyle, M. P.; Duffy, R.; Ratnikov, M.; Zhou, L. Chem. Rev. 2010, 110 , 704-724. doi:10.1021/cr900239n

36. Heretsch, P.; Rabe, S.; Giannis, A. J. Am. Chem. Soc. 2010, 132, 9968-9969. doi:10.1021/ja103152k

37. Abbiati, G.; Arcadi, A.; Bianchi, G.; Di Giuseppe, S.; Marinelli, F.; Rossi, E. J. Org. Chem. 2003, 68, 6959-6966. doi:10.1021/jo0347260

38. The regioisomeric cyclization product (theoretically obtainable by fusion with the $\mathrm{C} 20$ methylene) was not detected in the crude reaction mixture.

39. After chromatographic purification the final product was obtained in ca. $90 \%$ purity (judged by ${ }^{1} \mathrm{H}$ NMR, see Supporting Information File 1 ). We were not able to determine the structures of the impurities or completely remove them. The yield reported takes this into account; the biological assay and the stability assay were run with this material. 


\section{License and Terms}

This is an Open Access article under the terms of the Creative Commons Attribution License

(http://creativecommons.org/licenses/by/2.0), which permits unrestricted use, distribution, and reproduction in any medium, provided the original work is properly cited.

The license is subject to the Beilstein Journal of Organic Chemistry terms and conditions:

(http://www.beilstein-journals.org/bjoc)

The definitive version of this article is the electronic one which can be found at:

doi:10.3762/bjoc.10.161 